\title{
Old proverbs for a future sustainable development: An environmental management perspective
}

\author{
Cezar Scarlat ${ }^{1}$, Alexandru-Ionuţ Petrişor (i) 2, 3, *, \\ 1 Politehnica University of Bucharest, cezarscarlat@yahoo.com \\ 2 "Ion Mincu" University of Architecture and Urbanism, \\ 3 National Research Institute for Tourism, Bucharest, Romania. \\ * Correspondence: alexandru_petrisor@yahoo.com
}

Keywords: ancient wisdom, proverbs, environmental management, environmental protection, environmental law, sustainable development

\begin{abstract}
Although the concept of "sustainability" is attributed to Dr. Gro Harlem Brundtland, the principle of inter-generational equity substantiating it is older, at least in the Romanian tradition. This article attempts to take the first steps in looking for the roots of environmental sustainability starting from the traditional wisdom synthesized in proverbs, focusing on the sustainable environmental management. For this purpose, the universal and international principles of environmental law, which are interconnected to the concepts of environmental management (responsibility for protecting the environment) and scientific management in general (functions of the management, decision theory) are used as the backbone of a taxonomic approach. The concept of managerial responsibility takes in ecology the form of individual, group and collective responsibility for the decisions and actions related to the protection of the environment, and also the form of social responsibility. This study continues previous researches of the authors, opening the way to other trans- and interdisciplinary studies. Its main limitation (to Romanian proverbs) gives a possible direction for further research.
\end{abstract}

\section{Introduction}

The concept of "sustainable development" is attributed to Dr. Gro Harlem Brundtland, former Prime Minister of Norway and Chairman of the United Nations World Commission on Environment and Development. However, Dr. Brundtland can be credited for the term that coined the concept, because the basic principle of sustainability "development that meets the needs of the present without compromising the ability of future generations to meet their own needs" (Brundtland, 1987) - is older, at least in the Romanian tradition. Thus, the Romanian writer Barbu Ştefănescu-Delavrancea attributes to Ştefan cel Mare, King of Moldova (1457-1504) the words "Moldova did not belong to my ancestors, does not belong to me or to you, but to your offspring and to the offspring of your offspring, now and into the ages to come" (Ştefănescu-Delavrancea, 1909). Be these words said in the 1400's or written in 1909, they reflect the same idea as Dr. Brundtland's concept. In addition, historical documents might reveal many other perhaps older sources pointing out to the current care for the generations to come.

Similarly, in a 2003 interview (Bugge and Watters, 2003), Dr. Gro Harlem Brundtland points out to the fact that the intended meaning of sustainability consisted of integrating the existing pillars (economy, society, and environment), and eventually the newer 
cultural one, of equal importance (Todoran and Patachi, 2015). The idea is not new either; Haken created the term "synergetics" in 1977 in order to stress out the need for interdisciplinary approaches to the study of systems, but the idea of trans-disciplinarity is even older, although the hierarchical classification of concepts like multi-, inter-, and trans-disciplinarity is relatively new (Petrişor, 2013).

Without diminishing the merits of Dr. Gro Harlem Brundtland, this article attempts to start a quest for the older roots of environmental sustainability in the common wisdom synthesized in proverbs, focusing on sustainable environmental management. After all, the studies on the profound significance of old proverbs and their surprising echo (at a first sight) in relationship to the principles of modern management modern are a Romanian premiere (Scarlat, 2007; 2015; 2019:19).

For this purpose, the universal and international principles of environmental law will be used as a backbone, merely in a taxonomic manner.

Although the starting point of the article is the set of universal and international principles of environmental law, it has to be noticed that many of these are interconnected to the concepts of environmental management and scientific management in general, such as the functions of the management, decision problems (short versus long term decision), responsibility principle, and management of resources. Although the debate over the primacy of domains (law versus management) is beyond the scope of this article, apart from the trans- and interdisciplinary character of the study, the convergence of law and management is equally important. The authors preferred the perspective of environmental management, illustrate by proverbs.

\section{Principles of environmental law}

Different authors propose a variety of principles of environmental law, labeled - often in an interchangeable manner - as "international" or "universal" (Lupan, 1996; Marinescu, 2003; Boroi and Gorunescu, 2007; Mohorea et al., 2009; Petrescu-Mag, 2011; Duţu, 2010; Hanciu, 2015; Ilinca, 2016). These principles refer to the two sides of environmental degradation, from an economic perspective: depletion of environmental resources and generation of pollution and other forms of environmental degradation. Based on the correspondences between different sources, the following lists (universal and international principles) were compiled.

\section{A. Universal principles}

(1) The environment is a reality belonging to the historical evolution of natural systems; mankind must design its activities in accordance with the laws of this evolution, and undertake no actions setting a negative course to it; mankind inherited and benefits upon the natural capital.

(2) The environment is a global entity with local particularities and has no borders; local actions can have regional and global consequences, and global changes can have local outcomes.

(3) Environment is the source and support of life; human communities are an integrated part of the environment, and their existence and development depends on it (the grounds of sustainability). 
(4) The environment has the right to be protected, preserves and enhanced; these actions ensure the observance of the fundamental rights of mankind to life, to a healthy environments, to welfare, to civilization and progress.

(5) The environment is a good of major public interest of human communities and humanity (common heritage).

(6) Other individual or group interests must yield to environmental protection, except for providing health, protection and security, preventing natural hazards, and ensuring the local subsistence means.

(7) Environmental protection measures must have a preventive character, provided that the degradation of the environment implies cascaded phenomena (in time and space), and environmental restoration is unlikely and costs more than prevention.

(8) Responsibility - punishment and payment - for the environmental prejudices ("polluter pays" principle) and the obligation to restore the degraded systems in order to remove the prejudice.

(9) The principle of sustainable use of environmental resources unto the benefit of present and future generations - "beneficiary pays".

(10) The principle of local, regional, national, and global cooperation for enforcing the environmental law principles.

(11) Participation of local communities to the sustainable use of environmental resources and their rights to a correct and balanced distribution of benefits resulting from this use.

\section{B. International principles}

(1) The environment is a global entity with local particularities and has no borders; local actions can have regional and global consequences, and global changes can have local outcomes (same with previous Principle no. 2).

(2) States have sovereign rights to exploit their own resources according to their own environmental and development policies, but also the duty to cause no damage to other countries or regions without national jurisdiction.

(3) The principle of protecting common heritage and the universal one.

(4) The principle of informing and cooperating with other countries, including notification and consulting.

(5) The "good neighbor" principle - satisfying mutual interests.

(6) The principle of responsibility for the environmental prejudices (same with previous Principle no. 8).

\section{Proverbs corresponding to the identified principles}

Noticing that principles (12) and (2), also (17) and (8) are equivalent, the proverbs have been assigned to 15 principles of environmental law, numbered (1) to (15). For each of them proverbs were identified in a representative collection (Botezatu and Hîncu, 2001). Results follow below. Proverbs are structured as illustrative, equivalent and (slightly different, but) in the same spirit and are followed by comments, and, wherever appropriate, adequate references. Since the proverbs were Romanian, translations was done by picking the English equivalent proverb, if available, or translating the meaning of the proverb, and not the words. 
Principle (1): The environment must not be harmed.

Proverbs

He who spits in the wind spits in his own face. (Romanian: Cine scuipă în vânt, îşi scuipă barba.)

Proverb in the same spirit

The sun cannot be glued with mud, and wholes in the sky cannot be covered by hands. (Romanian: Soarele nu se lipeşte cu tină şi nici cerul nu se căptuşeşte cu palma.)

\section{Comments}

Prejudicing (polluting) the environment is not an interdiction by itself, but it is motivated by the negative effects, i.e. the impact on the polluter oneself. The proverb illustrates admirably this pervert effect: "He who spits in the wind" (polluter) suffers immediately an undesired effect ("spits in his own face"). The causal relationship is manifested directly, unpleasantly, but unavoidably.

One prejudiced, the environment (metaphorically: "the sun" and/or "the sky") must be restored using commensurate methods and resources, but certainly not using low quality materials ("with mud") or inadequate methods (using the "hands").

[See also Principle (4)].

Principle (2): Local actions affect the global environment.

Proverbs

A chain is only as strong as its weakest link. (Romanian: Când se rupe o verigă, tot lanţul se desface.)

\section{Equivalent proverb}

A rolling stone draws many other stones after it. (Romanian: Piatra când se rostogoleşte multe alte pietre trage după ea.)

Proverbs in the same spirit

Where do you hit it, and where does it crack? (Romanian: Unde dai şi unde crapă?)

When you drink water, think of the source. (Romanian: Când bei apă, gândeşte-te la izvor.)

\section{Comments}

The metaphor of the chain from the first proverb is an admirable illustration of the local-global relationship (respectively "link"-"chain"), in a positive (the strength of a chain is given by the strength of its composing links) but especially negative sense: a local problem ("weakest link") has global consequences (over the "chain").

The second proverb is equivalent form the viewpoint of negative consequences: a single "a rolling stone" (a local action) affects the global environment ("draws many other stones").

Proverbs in the same spirit are relevant for the multiple cause-effect relationships between the local actions ("where do you wit", "the source") and ultimate effects, an often unexpected impact ("where does it crack?", "when you drink water") - over the global environment. 
Principle (3): Mankind is an integrated part of the environment.

Proverbs

The forest is the Romanian's brother. (Romanian: Codru-i frate cu românul.)

Proverb in the same spirit

Many time a tree would do what a man won't do. (Romanian: De multe ori, ce nu biruieşte omul biruieşte pomul.)

\section{Comments}

Ecology defines mankind as a central element of the global society-man-nature system. This is also in line with Principle 1 of the Rio Declaration (UN, 1992), according to which "Human beings are at the centre of concerns for sustainable development".

In proverbs, as in the entire folk literature "the forest" is a symbol of nature (natural environment) and the "Romanian" (symbol of the human element) is not only an integrant part of the environment, but also in a special relationship to it - even "brother".

The second proverb remarks that, in relationship to nature, mankind is sometimes subject to greater natural forces (e.g., natural cataclysms).

Principle (4): A healthy environment warrants the fundamental rights of mankind.

Proverbs

Don't spit into the water fountain, because you will drink water out of it. (Romanian: Nu scuipa în fântână, că vei bea apă din ea.)

Equivalent proverb

Don't stir in the fountain that satisfied your thirst. (Romanian: Nu tulbura fântâna care tii-a potolit setea.)

Proverbs in the same spirit

The snake doesn't bite if you don't step over it. (Romanian: Şarpele până nu-I calci, nu te muşcă.)

Don't step over the snake's tail, if you don't want it to bite you. (Romanian: Nu călca şarpele pe coadă, dacă nu vrei să te muşte.)

\section{Comments}

The "fountain" is the health natural environment (which must not be polluted "spitting" or "stirring [it] in"); it is also the healthy living environment (thirst is "satisfied" and we "drink water" needed for life). Water - symbol of life - ensures for our living benefiting upon the fundamental rights of mankind: to life, a health environment, welfare, civilization, and progress.

The next proverbs are similar metaphors, but include strong warnings: the "snake" is the nature that should not be perturbed by unwise actions ("the snake" must not be stepped "over [its] tail") because the effects can be devastating (the bit of the snake can be mortal). 
Principle (5): Environment is a good of major public interest.

Proverbs

The sun doesn't rise for a single person. (Romanian: Soarele nu răsare numai pentru un om.)

Equivalent proverbs

There is room under the sun for everyone. (Romanian: E loc sub soare pentru toţi.)

The sun warms up the good and the bad. (Romanian: Soarele încălzeşte şi pe buni şi pe răi.)

\section{Comments}

The environment is a good of major public interest - common world heritage.

Thus, what symbol could be more appropriate for the common world heritage than the Sun? The sun rises for the entire world, "there is room under the sun for everyone", without any discrimination (race, nationality, religion, gender, or age) - same "the good and the bad".

Principle (6): Environmental protection prevails over other interests.

Proverbs

Gluttony spoils humanity. (Romanian: Lăcomia strică omenia.)

He who grabs much, little has. (Romanian: Cine apucă multe, puţine are.)

Speed spoils the job. (Romanian: Graba strică treaba.)

Hesitation spoils the job. (Romanian: Zăbava strică treaba.)

Equivalent proverbs

Being stingy for the bran. (Romanian: A te scumpi la tărâţe.)

The lazy one runs more, and the stingy one looses more. (Romanian: Leneşul mai mult aleargă şi scumpul mai mult păgubeşte.)

Proverbs in the same spirit

Don't throw the baby out with the bathwater. (Romanian: A arunca şi copilul odată cu apa din copaie.)

Don't set the mill on fire to burn out the mice. (Romanian: Ca să ardă şoarecii nu da foc morii.)

\section{Comments}

The issue of different interests - diverse and often contradictory natures - is a management problem, and its solution, multi-criteria decision. Multi-criteria decisions are taken based on ranking the importance of decision criteria, respectively the priorities, according to the decision theory (von Neumann and Morgenstern, 1953; Raiffa, 1997).

Although the selected proverbs seem to be far from the environmental issue and different one from each other, they illustrate all together the same mistake made when deciding, i.e., wrong ranking of priorities. As - metaphorically speaking - "humanity" and well done "job" [for protecting the environment] are more important than "gluttony" and, respectively, "speed" / "hesitation", the protection of the environment is more important than other irrelevant or narrow-scoped interests. 
The desire to "grab much" can be interpreted as gluttony or tendency to avoid ranking the priorities and considering all decision criteria equally important.

Equivalent proverbs insist on the negative effects of the wrong priority ranking, while the last two proverbs underline, with a dark humor, the serious consequences of the same error (loosing the child, setting the mill on fire).

Principle (7): Environmental protection must be done preventively.

\section{Proverbs}

Instead of paying for the evil, better don't do it. (Romanian: Decât să plăteşti pagube, mai bine să nu le faci.)

Be sorry when doing, not when repenting. (Romanian: Să-ţi pară rău când făptuieşti, nu când te pocăieşti.)

Good prevention help passing over the bad danger. (Romanian: Paza bună trece primejdia rea.)

Equivalent proverbs

The smart man buys his sledge in the summer and his carriage in the winter. (Romanian: Omul deştept cumpără vara sanie şi iarna căruţă.)

Take care of your winter coat during the summer. (Romanian: De cu vară, pentru iarnă, de cojoc să te-ngrijeşti.)

Set the candle on fire before the night comes. (Romanian: Aprinde lumânarea înainte de a se face noapte.)

Before getting in, think about the way to get out. (Romanian: Până a nu intra, socoteşte cum ai să ieşi.)

Proverbs in the same spirit

The bunny hops from wherever you don't think. (Romanian: De unde nu gândeşti, de acolo sare iepurele.)

The squeaking tree never falls down without a reason. (Romanian: Copacul care scârţâie nu cade degeaba.)

Great fire can follow a small spark. (Romanian: Focul în pădure din scânteie mică se aprinde.)

The water comes into the big ship through a small crack. (Romanian: Printr-o crăpătură mică răzbate apa în corabia mare.)

Should the man know what will happen to him, he would be cautious. (Romanian: De-ar şti omul ce-ar păţi, dinainte s-ar păzi.)

\section{Comments}

Starting from Taylor (1911) and Fayol (1917) up to Koontz and Weihrich (2010), authors agree that the first function of management is planning based on foreseeing the consequences.

From an environmental management perspective, preventive environmental protection measures can avoid future costly damages ("paying for the evil").

Thus, a good manager ("smart man") anticipates the future situations (invariably, in the astronomic cycle day follows the night and winter the summer) and plans accordingly, in time, a "good prevention" for the future situations when he must pass the "bad danger" 
("set[s] the candle on fire before the night comes"; "buys [a] sledge" during the summer etc.)

Proverbs from the last group use metaphors familiar to the protection of the environment (forests, water, fauna) underlining - on the one hand - the sometimes hardly predictable character of future situations ("bunny hops from wherever you don't think") and - on the other hand - the importance of weak signals (Ansoff, 1975) needed for building early warning (Zuzak, 2017) systems.

The squeak of a tree before its falling is a weak signal useful for prediction and prevention. Still metaphorically, the "small spark" before the "fire" that can devastate the forest or "small crack" in the wood that forecast a possible wreck of the "ship" are early warning signals.

The last proverb follows the same temporal logic, but the conditionality expressed by it ("should know") has a negative, fatalist connotation (possibly characteristic to the Romanian people).

Principle (8): Mankind responds for prejudicing the environment.

Proverbs

He who mistakes, pays. (Romanian: Cine greşeşte, plăteşte.)

Equivalent proverbs

He who mistakes, suffers. (Romanian: Cine greşeşte, pătimeşte.)

He who does not open the eyes, will open the wallet. (Romanian: Cine nu deschide ochii, deschide punga.)

Proverbs in the same spirit

Each sin is looking for its sinner. (Romanian: Tot păcatul îşi caută vinovatul.)

There's no fact without reward. (Romanian: Nu-i faptă fără răsplată.)

The reward follows the guilt. (Romanian: După faptă, şi răsplată.)

He who does, be it done to him. (Romanian: Cine face, facă-i-se.)

He who seeds wind shall harvest storm. (Romanian: Cine seamănă vânt culege furtună.)

It came out as it was seeded. (Romanian: Cum a fost sădit, aşa a răsărit.)

Do evil and you'll find evil. (Romanian: Rău faci, rău găseşti.)

Don't do evil, because it will come after you. (Romanian: Nu face rău, că te va ajunge.)

If you seed evil, then you'll harvest even worse. (Romanian: Rău de vei semăna, şi mai rău vei secera.)

He who rolls the stone will hit himself. (Romanian: Cine piatră rostogoleşte, pe el se loveşte.)

He who does evil cannot get out of troubles. (Romanian: Cine face tot la rele, el nu scapă de belele.)

\section{Comments}

Responsibility is a key principle of management ("the head does, the head stands for $\left.i^{\prime \prime}\right)$. In the environmental management, the concept of responsibility expands from individual responsibility to the group/community one. For this reason, proverbs - 
individual metaphoric expressions - must be interpreted under the key of collective responsibility. As a consequence, human responsibility - in its broad meaning - for prejudicing the environment is at the base of the management of sustainability: the polluter ("he who mistakes" or does not carry out his duty and does not "open the eyes") will suffer the consequences ("pays", "open the wallet" or "suffers").

Proverbs in the same spirit are numerous and illustrate: (i) a symmetric punishment - according to the biblical principle "an eye for an eye and a tooth for a tooth" ("evil" for "evil"; "who does, be it done"; "if ... then"); (ii) a divine punishment that will fatally "come after" the guilty in a form or another (symbol of the thrown "stone"); (iii) an amplified punishment - declared directly ("wind" - "storm") or only suggested (payment "reward"; "evil" - "troubles"); (iv) the legal punishment - seeking for the "sinner" to be punished for his fact ("sin") [prejudicing the environment].

\section{Principle (9): Natural resources must be safeguarded for the future.}

\section{Proverbs}

Shear the sheep, but don't take its skin off. (Romanian: Tunde oaia, dar nu-i lua şi pielea.)

Don't kill the hen that lays the golden eggs. (Romanian: Nu tăia găina care face ouă de aur.)

Only a fool would cut off the tree to eat its fruits. (Romanian: Prostul taie pomul ca să-i mănânce rodul.)

\section{Equivalent proverbs}

If you keep taking and don't put pack, it would end. (Romanian: De unde tot iei şi nu pui, curând se isprăveşte.)

The bag from which you take and don't put back would get empty. (Romanian: Sacul din care tot iei şi nu mai pui, se goleşte.)

Put back wherever you are taking it from. (Romanian: Pune la loc de unde iei.)

Proverbs in the same spirit

You will sleep as you are laying it down. (Romanian: Cum îţi vei aşterne, aşa vei dormi.)

You will eat as you cook. (Romanian: Cum îţi vei găti, aşa vei prânzi.)

Think today of what you will eat tomorrow. (Romanian: Gândeşte de azi ce vei mânca mâine.)

Don't forget about tomorrow, so you won't long for the bread. (Romanian: Nu uita ziua de mâine, ca să nu duci dorul de pâine.)

Suffer one hour and you will live an year. (Romanian: Rabdă un ceas şi vei trăi un an.)

\section{Comments}

[See also Principle (7) - for other proverbs illustrating the anticipatory spirit]

Natural resources are a good limited not only in space, but also in time and consequently - must be managed ensuring that the future generations could also benefit upon them. 
In other words, the management (present decisions) on the consumption of natural resources must be optimized in order to prevent their exhaustion / destruction. A very good example is the well managed forest - would is cut off as much as regeneration is still possible, and hunting is made preserving the balance and preventing the disappearance of game.

Since the wise management of resources (accounting for their long term efficiency) is an old practical activity, its proverb illustration is rich too.

This aspect of a wise management of natural resources is underlined by the selected proverbs: the resources ("the ship", "the hen", "the tree") must not be destroyed (cut off or sacrificed) or exploited excessively, up to destruction ("don't take its skin off" or "kill the hen") to prevent cutting of their reasonable benefits (wool from shearing the "ship", "fruits" or "golden eggs").

The equivalent proverbs are more explicit for the maintenance / management of natural resources (replanting the forests, providing enough food for its animals etc.)

The proverbs in the same spirit warn over an important aspect of life quality - also metaphorically (as one "will eat" and "will sleep" in the future depends on the present decisions).

The last proverb also illustrates an important management problem: the short term ("an hour") versus the long term decision ("an year"). The significance is double: the future value is greater than the present one (a year is more than an hour), even if the future results builds up on present savings ("suffer one hour").

Principle (10): Cooperation is needed for applying the environmental law principles.

Proverbs

One hand washes the other and both wash the face. (Romanian: O mână spală pe alta şi, amândouă, faţa.)

Equivalent proverbs

The wolf cannot kill the oxen coming together to the pasture. (Romanian: Boii uniţi la păşune, lupul nu-i poate răpune.)

Proverb in the same spirit

Water first your garden, and then your neighbor's one if you still have water. (Romanian: Udă întâi grădina ta şi, de-ţi mai rămâne apă, udă şi pe a vecinului.)

\section{Comments}

An excellent illustration of this principle is the way how local cooperation ("one hand washes the other") contributes to enforcing the environmental law principles globally ("both [hands] wash the face"); the face can be washed by hands only!

The equivalent proverb also shows how local cooperation (cattle "together to the pasture") can defend the common environmental protection interests (even the cattle + pasture ecosystem) - this time, against an external danger ("wolf").

Although own interests come first [see Principle (12)], cooperation cannot be denied; if you can and still have resources ("if you still have water") then you can contribute to protecting the environment (watering not only "your garden", but also "your neighbor's 
one"; in a broad sense, the "garden"). The wonderful metaphor garden nature (natural environment) is also noteworthy.

[See also Principle (14)]

Principle (11): Local communities are part of the environmental protection. Proverbs

Small streams make up the large rivers. (Romanian: Apele mici fac râurile mari.)

Equivalent proverb

The big lake is made drop by drop. (Romanian: Picătură cu picătură face lacul mare.) Proverb in the same spirit

Wherever a village spits, a lake comes out. (Romanian: Unde scuipă un sat se face un lac.)

\section{Comments}

Local communities ("small streams", "drops") are part of the defining structure of the global system man-society-nature - even by the direct meaning ("large rivers" and "big lake"). This is also in line with Principle 1 of the Rio Declaration (UN, 1992), according to which "Human beings are at the centre of concerns for sustainable development".

Local environmental protection leads implicitly and organically to the global environmental protection and reciprocally, and benefits, from an environmental protection viewpoint, are mutually advantageous.

In the same spirit, risking a trivial metaphor with a doubtful quality, the last proverb can have a positive meaning if thinking of the significant environmental benefits obtaining an element with a environmental value ("a lake comes out") by recycling the waste, with no value and even harmful for the environment (what is "spits").

[See also Principle (2)]

Principle (12): Each one is sovereign over the own property.

Proverbs

There are as many habits as houses. (Romanian: Câte bordeie, atâtea obiceie.)

Proverbs in the same spirit

Water first your garden, and then your neighbor's one if you still have water. (Romanian: Udă întâi grădina ta şi, de-ţi mai rămâne apă, udă şi pe a vecinului.)

When your household is thirsty, don't spill out the water on the road. (Romanian: Când casa ta are sete, nu vărsa apă pe drumuri.)

Don't do unto others what you don't want done unto you. (Romanian: Ce ţie nu-ţi place, altuia nu-i face.)

\section{Comments}

According to this principle, states have the sovereign right to exploit their own resources according to their environmental and development policies, but also the duty not to damage the environment of other states or regions with no national jurisdiction according to the Latin proverb sic utere tuo ut alienum non laedas (use your own property in such a way that you do not injure other people's). 
In other words, each state takes the best decisions for its own interests (which differ from a state to another, because there are "as many habits as houses"). Moreover, own interests prevail ("water first your garden" and satisfy the thirst of your "household"). However, the satisfaction of own interests (what you like) is limited; it must be in agreement with the interests of other states, or at least not be detrimental to other states ("don't do unto others what you don't want done unto you").

\section{Principle (13): Common heritage must be protected.}

Proverbs

More arms bring more fruits. (Romanian: Braţe multe aduc mai multă roadă.)

Many heroes come to do good deeds. (Romanian: La o faptă bună, mulţi voinici se-adună.)

\section{Comments}

The common heritage and the heritage of universal value (tree of many "fruits") must be protected by all states/ many member organizations responsible ("many heroes" with more arms") through responsible environmental protection actions ("good deeds").

Principle (14): Environmental protection implies the cooperation of stakeholders.

Proverbs

People hope from other people. (Romanian: Om la om trage nădejde.)

Equivalent proverb

Friends show their love in times of trouble, not in happiness. (Romanian: Prietenul la vreme de nevoie se cunoaşte.)

Proverbs in the same spirit

Strength is in union. (Romanian: În unire stă tăria.)

Union makes the power. (Romanian: Unirea face puterea.)

Wherever there's only one, there's no power; wherever there are many, there's more power. (Romanian: Unde-i unul, nu-i putere, unde-s mulţi, puterea creşte.)

\section{Comments}

The environmental protection presumes the cooperation of parts as equal partners ("from other people"); they can rely one on each other with justified hope ("hope") in different form of help - exchange of information, notifications and consultations.

The equivalent proverb illustrates especially the cooperation (of "friends") as help "in times of trouble" or even in extreme situations - crisis or emergency.

The last proverbs underline the solidarity and synergetic character of associations ("union") that ensures reaching the goals ("makes the power", "[is the] strength") / the success of [environmental protection] actions. Without cooperation ("wherever there's only one"), the objectives cannot be reached because "there's no power".

[See also Principle (10)] 
Principle (15): Protection of common goods yields common benefits.

Proverbs

Even a hostile neighbor runs to extinguish the burning house. (Romanian: La casa aprinsă şi vecinul vrăjmaş aleargă să o stingă.)

Proverbs in the same spirit

Do a good deed today, and tomorrow someone will return it to you. (Romanian: Dacă faci azi un bine, mâine de la altu-ţi vine.)

Reward the good by good. (Romanian: Binele cu bine se răsplăteşte.)

If it yields in your place, we'll have some too. (Romanian: S-o face la voi, vom avea şi noi.)

\section{Comments}

The good neighboring principle and cooperation for protecting common goods can yield benefits to both sides - in concordance with the theory of cooperative games (von Neumann and Morgenstern, 1953; Luce and Raiffa, 2012).

Good neighboring presumes help when needed ("the burning house") and cooperation in protecting the goods: the neighbor - even "hostile" - will hurry up ("runs") to help "to extinguish".

It is worthy noticing the use of the metaphor "house" as symbol of the common goods that must be first protected against an absolutely destructive danger (the fire).

For games with a sum different from zero, both partners can win (win-win). The proverbs in the same spirit underline this very aspect of gain, even if not simultaneous: "do a good deed today" today and gain will come tomorrow. But it will come because "reward the good by good".

The last proverb, although in the same spirit of mutual gain, bears, in a certain measure, a fingerprint of fatalism passivity: "we'll have some" only if "it yields in your place".

\section{Discussion on responsibility: Origin and evolution}

The issue of responsibility - as a key principle of management - deserves a separate discussion, not only from the environmental management view point, as base for the management of sustainability. The responsibility concept, extended from the individual to the group/community responsibility, has undergone a complex metamorphosis - not only as collective responsibility in its broader sense - human responsibility for the prejudices of the environment / see Principle (8) - but also as social responsibility. However, this is beyond the scope of this article.

However, from the environmental management perspective it is worthy mentioning that group (collective) responsibility is also accepted in a time perspective - over the generations. Its origin can be as early as the Bible: the Ten Commandments received by Moses for his people must be observed under strict punishments: "the iniquity of the fathers on the children to the third and the fourth generation... but showing steadfast love to thousands of those who love me and keep my commandments" (Broşteanu and Băltăceanu, 2013:160; NKJW translation).

Two issues are noteworthy: (i) the old existence of the conception on collective responsibility ("children paying for the sins of their parents") and (ii) the way to 
educating and developing the individual responsibility is long and passes through stimulating (rewarding) "thousands of generations" opposed to the punishment, limited to few generations. The almost cosmic dimension of mercy "also has the role of suggesting the immensity of divine mercy" (Broşteanu and Băltăceanu, 2013:160).

\section{Conclusions, limitations and future research}

The current principles of environmental law are naturally interconnected with the concepts of environmental management (responsibility for the protection of the environment) and of scientific management in general (functions of management, decision theory).

The current principles of environmental law and concepts of environmental management can be sustained and illustrated by cases-examples (Romanian proverbs in this study); this represents an original approach and contribution.

The concept of managerial responsibility emerged only a century ago, along with the fundamentals of scientific management (Taylor, 1911; Fayol, 1917), takes in ecology the form of individual, group and collective responsibility for the decisions and actions related to the protection of the environment, and also the form of social responsibility. However, it is worthy noticing that the concept has older roots (Code of Hammurabi, circa $1760 \mathrm{BC}$ and the Bible) under the form of multi-generational collective responsibility, with a complex evolution until today.

This study continues a series of previous researches of the authors - dealing with the managerial significance of proverbs and, respectively, environmental law and sustainability, opening the way to other trans- and interdisciplinary studies. Its main limitation (to Romanian proverbs) also constitutes a possible direction for continuing and developing the research.

\section{References}

1. Ansoff H. I. (1975), Managing Strategic Surprise by Response to Weak Signals, California Management Review 18(2): 21-33.

2. Botezatu G ., Hîncu A. (2001), Dictionary of Romanian proverbs and sayings [in Romanian], Litera Internaţional Press, Chişinău, Moldova.

3. Broşteanu Monica, Băltăceanu Francisca (2013), The most beautiful stories of the Bible. The First Covenant. Chapter "Israelites at Mount Sinai. The Ten Commandments, translation from Hebrew, Aramaic and Greek from the Bible - Exodus 19: 1-12, 16-20; 20: 1-17, Humanitas, Bucharest, Romania.

4. Brundtland Gro Harlem (1987), Our Common Future, WCED, Oxford University Press, Oxford.

5. Bugge H. C., Watters L. (2003), A Perspective on Sustainable Development after Johannesburg on the Fifteenth Anniversary of Our Common Future: An Interview with Gro Harlem Brundtland, Georgetown International Environmental Law Review 15:359-366.

6. Duţu M. (2010), Environmental law [in Romanian], 3rd Edition, C. H. Beck Press, Bucharest, Romania.

7. Fayol H. (1917), Administration industrielle et générale; prévoyance, organisation, commandement, coordination, controle, H. Dunod et E. Pinat, Paris, France.

8. Haken H. (1977), Synergetics: an introduction. Nonequilibrium Phase Transitions and Self-Organization in Physics, Chemistry, and Biology, Springer-Verlag, Berlin, Germany.

9. Hanciu Oana-Maria (2015), International responsibility of states for transboundary environmental damages [in Romanian], doctoral thesis, Nicolae Titulescu University, Bucharest, Romania.

10. Ilinca Alexandra (2016), Environmental law: course notes [in Romanian], Sitech, Craiova, Romania.

11. Koontz H., Weihrich H. (2010), Essentials of Management - An International Perspective, 8th Ed., Tata McGraw Hill, New Delhi, India. 
12. Luce R. D., Raiffa H. (2012), Games and Decisions: Introduction and Critical Survey, Revised edition, Dover Publications, Chicago, IL, USA.

13. Lupan E. (1996), Environmental law: Generalities [in Romanian], Lumina Lex Press, Bucharest, Romania.

14. Marinescu Daniela (2003), Treaty on environmental law [in Romanian], All Back Press, Bucharest, Romania.

15. Mohorea E., Botnari Elena, Eşanu R. (2009), Law as a system and the system of law [in Romanian], Presa Universitară Bălţeană, Bălţi, Moldova.

16. Petrescu-Mag Ruxandra-Mălina (2011), Environmental protection in the context of sustainability. Legislation and institutions [in Romanian], BIOFLUX Press, Cluj-Napoca, Romania.

17. Petrişor A.-I. (2013), Multi-, trans- and inter-disciplinarity, essential conditions for the sustainable development of human habitat, Urbanism Architecture Constructions 4(2): 43-50.

18. Petrişor A.-I., Petrişor Liliana Elza (2014), 25 years of sustainability. A critical analysis, Present Environment and Sustainable Development 8(1): 175-190.

19. Raiffa H. (1997), Decision Analysis: Introductory Lectures on Choice under Uncertainty, McGraw Hill, USA.

20. Scarlat C. (2007), Teaching decision-making process through proverb-cases: 12 Romanian proverbs, in: Proceedings of the Eighth International Conference on Operational \& Quantitative Management (ICOQM-8) "Emerging Perspectives of Decision Making in a New Globalized World: Theory, Practice and Future Directions", October 17-20, Bangkok, Thailand, pp. 400-406.

21. Scarlat C. (2015), Book of Management Proverbs [in Romania], Printech Press, Bucharest, Romania.

22. Scarlat C. (2019), One Hundred of Romanian Proverbs for 100 Years of Modern Management [in Romanian], Niculescu Press, Bucharest, Romania.

23. Ştefănescu-Delavrancea B. (1909), Sunset [in Romanian], Socec Press, Bucharest, Romania.

24. Taylor F. W. (1911), The Principles of Scientific Management, Harper \& Brothers, New York, USA.

25. Todoran Smaranda M., Patachi Laura (2015), Cultural Sustainability and Issues of Urban Memory, Acta Technica Napocensis: Civil Engineering \& Architecture 58(4): 227-234.

26. United Nations (1992), Rio Declaration on the Environment and Development, Principle 1, http://www.un.org/documents/ga/conf151/aconf15126-1annex1.htm

27. von Neumann J., Morgenstern O. (1953) [1944], Theory of Games and Economic Behavior, Third Edition, Princeton University Press, Princeton, NJ, USA.

28. Zuzak R. (2017), Early warning systems for strategic and crisis management, in Slavičková P. (Ed.), Proceedings of the International Scientific Conference "Knowledge for Market Use 2017: People in Economics - Decisions, Behaviour and Normative Models, Olomouc, Czech Republic, pp. 459-463. 